\title{
THE ROLE OF THE AUDIT AND AGENCY THEORY
}

Janet L. Colbert, Auburn University

John S. Jahera, Jr., Auburn University

\begin{abstract}
The audit function exists to monitor the activities of management and to attest to management's performance. The cost of the audit function is an example of an agency cost. This article discusses the role of the audit function within the context of agency relationships. Such relationships exist when one party is retained to act on behalf of and in the interest of another party. Given the natural preference to maximize one's own utility, conflicts are bound to arise. Knowledge of such potential conflicts can serve to reduce the cost of the resolution of these conflicts.
\end{abstract}

\section{INTRODUCTION}

The audit function has come under increased scrutiny in recent years because of business failures and alleged audit failures. Auditors have been criticized for not disclosing information which may have alerted investors to a possible business failure.

While the failure of a business does not prove that the auditor's disclosures were not sufficient, investors may assert that such is the case. In answer to pleas from the public to provide them with more information, the role of the audit is of necessity expanding beyond a simple verification of transactions and accounts. Auditors are now attesting to qualitative assessments of the strategies outlined by the management of the firm.

Managements of firms with different ownership structures may develop different corporate strategies. When performing the attest function, auditors should be aware of strategic differences which firms with different ownership structures may have. This paper examines the role of the audit function within the context of agency relationships. Agency theory can help explain the role of the auditor and the items of audit significance which may arise from various ownership structures. The theory can also explain the relationship the internal auditor has with the external auditor, and the relationships the auditors have with the management, the board of directors, and the shareholders. Finally, the theory can explain the amount of audit which is demanded.

The following sections present a brief overview of agency theory and then discuss the role of the audit function given the presence of agency relationships and different ownership structures and the quantity of audit that the client uses.

\section{AGENCY THEORY}

Agency theory attempts to explain a loss in value or wealth which occurs whenever one party acts (as the agent) for another. Such is the situation in the typical corporation where management (the agent) is hired to operate a firm for the shareholders (the principals). Historically, this agency relationship between shareholders and managers has represented the reason for 
the existence of an audit, either internal or external. Agency theory suggests that individuals tend to make decisions which will be of benefit to them. This follows from the basic economic theory of non-satiation of wants. The theory states that individuals prefer more to less and will seek to maximize their personal utility. Shareholders hire managers in the hope that the managers will maximize the shareholders' wealth.

A basic conflict of interest arises when managers are hired to represent the interests of owners. The manager would like to make decisions which will benefit him or her. Any decision made by management which leads to a loss in wealth or foregone wealth to the shareholders represents an agency cost. Any activity undertaken by shareholders to protect against less than optimal decisions also represents an agency cost. The shareholders are faced with a tradeoff of costs: a loss in wealth from management actions versus the cost of monitoring the activities of management. Traditionally, monitoring is done by the audit. The audit function exists to provide feedback to shareholders via the board of directors as to the behavior of managers. In the large corporation today, it is not feasible for each and every shareholder to be totally informed as to the daily ongoings of the firm. The cost of audit services represents an agency cost of equity.

\section{Growth of the Firm}

Agency theory provides the framework for the evaluation of the relationship between the various parties in the organization. To better understand the nature of the agency problem, consider the business organization from its inception. Usually, the initial organizational form is the proprietorship. In this organizational setting, the proprietor is typically the person who makes all of the decisions regarding the entity. Clearly, the goals of the business and the owner are one and the same and there should be no agency cost to the owner.

Even in a sole proprietorship, an agency relationship may arise. The proprietor may decide to bring in additional funds in the form of debt. At this point, the proprietor is in essence acting as the agent for the creditor in the management of the business. The proprietor now has an incentive to assume greater risk since other funds, those of the creditor, are at risk rather than the funds of the proprietor. That is, the proprietor may feel that expansion into a new product line carries a high risk of failure but that the cost of failure will be shared by the agent. Risk shifting behavior occurs with the creditor suffering an agency cost of debt due to the resulting discount in the value of the loan held by the creditor. For this reason, banks tend to monitor small businesses very closely. Generally, small businesses do not provide audited financial statements and in many instances the statements are incomplete or inaccurate. For the small proprietorship, the creditor is faced with the burden of determining the financial capacity and must assume the role of monitor in order to protect the funds the creditor has invested.

The next stage in the growth cycle of the firm is typically incorporation. The original proprietor may still have $100 \%$ of the shares. This indicates a zero agency cost of equity. However, creditors are still subject to the agency cost of debt. As the firm grows, it will become necessary at some point in time to bring in additional shareholders. These shareholders now face an agency cost of external equity: the external audit. That is, inside shareholders, directors and officers, clearly have access to information which is not always shared with outside shareholders. In addition, insiders have control over the daily operations of the firm. This affords them the opportunity to make decisions which may 
provide benefits to them at the expense of the outside or non-controlling shareholders. To mitigate these problems and provide the outside shareholders with information, the outside shareholders demand that an audit be performed. To compensate them for this agency cost, the outside shareholders demand a higher rate of return. This results in a lower stock price which is an agency cost of equity.

As the firm grows progressively larger with greater numbers of shareholders, the situation of no strong insider control or no strong coalition of outside shareholders may exist. Such a firm is, in effect, manager controlled. In this case, management is free to make decisions as they deem appropriate. The shareholders of a manager-controlled firm may decide that besides utilizing an external auditor who focuses primarily on the financial statements, an internal audit department is needed. While the financial statements are clearly of concern to the internal auditor, the internal auditors have broader interests. Internal auditors check for compliance with firm policies and procedures and are constantly searching for areas to improve in terms of operational efficiency and effectiveness. Internal auditors represent another agency cost of equity.

The audit function, either internal or external, represents a costly form of monitoring the activities of the various parties in the corporation. The next section attempts to address the importance of the audit in terms of reducing the agency costs.

\section{THE ROLE OF THE AUDITOR}

The expanding role of the audit function in today's corporation raises the question of the responsibility the auditor has to the participants in the corporation. The auditor represents one agent in this scenario. Knowledge that the auditor will be testing their work induces truthful reporting and adherence to policies by another agent, management. With an audit, shareholders and debtholders (the principals) are more confident that the information they receive is fairly presented. This confidence comes at the expense of an agency cost--the cost of the auditor. A question arises as to the responsibility of the auditors. That is, is there a potential conflict within the audit function? Are the auditors ultimately responsible to the party that pays their fees (the board of directors) or to the other parties who use their reports (the shareholders and creditors) ? To more clearly understand this dilemma, consider the role of the internal auditor versus the external auditor.

\section{The Role of the Internal Auditor}

The internal auditor typically reports to the board of directors or its audit committee and is charged with monitoring the activities of the firm to ensure that management is indeed acting in accordance with the policies established by the board of directors. The results of an internal audit are seen only by members of the board and are not available for other interested parties such as shareholders and bondholders. Any adverse information reported to the board by the internal audit staff may never be reported further. In order to receive information concerning the organization, the outside shareholders and debtholders must still incur an agency cost: the cost of the external equity.

In a manager-controlled firm, the internal audit cost is borne to benefit inside shareholders by offering some insurance against the expropriation of funds by managers. The external audit cost is paid to provide information to outside shareholders and debtholders of the firm. It is apparent that the internal audit provides no such insurance to outside interests.

The Role of the External Auditor 
If the board of directors utilized the information from the internal audit to benefit all shareholders and if third parties could rely upon the information, there would be no need for external audits. However, this is not the case. External auditors exist to provide information and monitor the activities of management for the outside parties in the corporate setting.

The distribution of the results of the external audit is typically broader than that of the internal audit. That is, the external audit is likely to be used by parties other than the board of directors. When performing the engagement, the external auditor must keep in mind the various users of the financial statements so that the report will be beneficial to them. The external audit provides information to bankers, investment analysts, bondholders and outside shareholders, as well as to insiders.

\section{Internal Versus External Audits}

Clearly, the focus which internal and external auditors take is different. The internal audit staff reports directly to the board of directors of a firm on the activities of management and is paid by the employer. The internal auditors have the incentive to respond to the wishes of those to whom they report. On the other hand, external auditors are typically retained for regulatory purposes and/or for requirements of lenders. Thus, although external auditors are also paid by the firm, they recognize a broader responsibility than that of the internal auditors. External auditors must critically examine the actions of not only management but the decisions of the board of directors since these impact all parties to the corporation. Although external auditors report to the board of directors, they are ultimately responsible to the shareholders, debtholders, and the public rather than to the client itself. In this respect, they must be aware of the potential areas of conflict between the desires of the various parties and be prepared to address such conflicts in the audit.

\section{THE AMOUNT OF AUDIT DEMANDED}

As noted earlier, the demand for an audit arises from shareholders and debtholders who are willing to pay for audits in order to insure that the firm is being managed in a way which best meets their interests. Both internal and external audits may be commissioned. To some extent, internal and external audits are substitutable services. Various factors influence both the total amount of audit demanded and the allocation of the work between the internal and external auditors. For example, a firm which has recently discovered a minor irregularity may ask the auditor to perform a more thorough examination of the system of internal control than is required for the financial statement audit and to make recommendations for improvement. This work could be performed by either the internal or external audit staffs. Two important factors which may influence the amount of audit demanded and the allocation of the effort are the agency relationships (proxied by the percent of stock held by insiders and the total number of shareholders) and whether an audit is required by a third party.

\section{Percentage of Insider Ownership}

Generally, the greater the amount of insider ownership, the less total audit is demanded. This is because less monitoring is needed. Insiders (officers and directors) are in the position to have full access to information. They are also the decision makers. Further, with greater inside ownership, the internal audit staff typically exerts relatively more of the total effort. The internal auditor not only tests the financial statements, but they also serve the insiders by making operational recommendations and reporting on compliance with management policies. 
Another reason that more inside ownership results in less total audit stems from the wage contract the firm has with management. One of the purposes of an audit is to produce information for shareholders so that an optimum contract can be developed. The shareholders would like an arrangement that provides incentive for management to perform well and increase the firm's value. A pure incentive (bonus) contract would meet this objective. However, under a pure incentive contract, management may bias the reported results. Also, because their total compensation depends on the firm's achievements, management bears a great deal of risk. Therefore, management may desire a pure wage arrangement. Shareholders see value in pure wages because truthful reporting of results is virtually assured. There is no management incentive to misstate earnings.

In practice, a combination wage and incentive contract is used. This reduces the risk to management while still providing them with an incentive. To mitigate the possibility of less than truthful reporting, the shareholders hire external auditors.

With more inside ownership, the compensation package is likely to be more pure wage and less incentive based. This reduces the risk to managers. Because less of the wage package is based on the results the firm achieves, there is decreased demand for an external audit. More of the audit effort is performed by the internal audit staff.

\section{Requirement to Have an External Audit}

Whether a firm is required to have an external audit or not may affect the quantity of audit demanded. A creditor may require an independent (external) auditor's opinion for example, or the firm may be regulated by an agency which requires an audit. These requirements may affect the focus the auditors take and the division of work between the internal and external audit staffs.

A firm required to have an audit may face reporting requirements that a non-regulated firm does not. The lender or regulatory agency (for example, the SEC) may demand disclosures that exceed those promulgated by generally accepted accounting principles. The client and ultimately, the board of directors, is responsible for the financial reporting, including disclosures and reports to the regulatory agency. Because of the consequences of incorrect or omitted information and because of the complexity of the transactions and reports, the board of directors of a regulated firm will contract for more assistance with these matters than a firm without such requirements.

The division of audit work between the internal and external auditors for a firm required to have an external audit is dictated by three factors: 1)the reporting requirements, 2)the relative value of external versus internal audits, and 3) the Foreign Corrupt Practices Act (FCPA) of 1977.

The first two factors are interrelated. Creditors or regulatory agencies may require an external audit because the opinion comes from an independent source. Firms required to have an external audit allocate at least the pure financial statement portion of the audit to the external auditor.

The FCPA of 1977 creates a demand for more audit work; this portion of the work is most likely performed by the internal audit staff. The FCPA requires that the firm establish and maintain a system of internal control. Either internal or external auditors are competent to help a firm establish and maintain controls and procedures to meet the specifications of the FCPA. However, throughout the year, the internal auditors are working with the firm's records. They are 
constantly in a position to make recommendations and to evaluate whether controls are operating as specified and whether policies are being followed. Also, internal auditors are generally less costly than external auditors. Thus, internal auditors are more likely to test for compliance with FCPA than external auditors.

\section{CONCLUSIONS}

Agency theory relates that the audit function exists to monitor the activities of management and to attest to management's performance for the benefit of the board of directors, the shareholders, and the debtholders. Basic economic theory says that individuals seek to maximize their own personal utility or level of satisfaction. The audit function provides some assurance that this goal is not being followed by managers and inside shareholders to the detriment of outside shareholders and debtholders.

Auditors should be aware of areas in which potential conflicts of interest may arise and be prepared to test these areas in their work. For example, in examining a sole proprietorship which has outstanding debt, the auditor should keep the creditors' interests in mind. For an incorporated firm, the internal auditors should address topics for the benefit of the board of directors such as compliance with policies and procedures while the external auditor should focus on disclosure for outside shareholders, debtholders, and regulatory agencies. Auditors should also be aware that firms will demand different amounts of audit and that the division of work between the internal and external audit staffs will vary for different firms. Firms with a large percentage of insider ownership will need less internal audit information since they are in the position to monitor daily operational activity themselves. The external audit effort will be greater for such firms since the outside shareholders and debtholders wish to assure themselves that the insiders are operating the firm in a prudent manner. By understanding the demand for the audit and the reasons for the division of work between the internal and external staffs, the auditor can seek to meet the needs of the parties utilizing the reports. 